\title{
Changes in the sublittoral faunal biomass induced by the discharge of a polluted river along the adjacent rocky coast $(\mathrm{N}$. Spain)
}

\author{
S. Pagola-Carte* , J. I. Saiz-Salinas \\ Department of Zoology \& ACD, University of the Basque Country, PO Box 644, 48080 Bilbao, Spain
}

\begin{abstract}
Sublittoral hard bottom assemblages in the 'Abra de Bilbao' bay (N. Spain) were described in terms of biomass in order to record spatial changes on scales of a few $\mathrm{km}$ that reflect the prevalence of perturbation gradients. Several criteria and levels of data aggregation were proposed and tested in an attempt to obtain information on the degree of redundancy achieved by such communities for further monitoring programmes. The area of study is at present recovering from a highly stressed situation of turbidity and sedimentation. In this way, the fauna/flora biomass ratio (A/V) proved to be a useful descriptor indicative of several environmental conditions from healthy to grossly perturbed on rocky communities. In addition, the high degree of redundancy shown by the macrozoobenthos allows efforts to be concentrated on only the faunal component, using different approaches and data aggregation levels. As a result, the cost-effectiveness of monitoring programmes could increase considerably. Moreover, the use of several techniques (univariate, multivariate) and approaches (taxonomic, trophic, mixed) is recommended for the monitoring of hard bottom communities, in order to test the robustness of the results obtained and achieve other complementary perspectives upon the biota with the same data sets. In this case study, relevant information was acquired on the possible temporal changes of intermediate zones of the 'Abra de Bilbao' due to the biological recovery of the area. Therefore, an adequate combination of biomass values and the concepts of redundancy-sufficiency is suggested as a realistic way of developing future monitoring programmes for rocky shores in other areas.
\end{abstract}

KEY WORDS: Monitoring - Macrozoobenthos - Sublittoral · Rocky shores · Biomass - Taxonomic redundancy · Fauna/flora ratio · 'Abra de Bilbao'

\section{INTRODUCTION}

Detecting ecologically significant changes related to habitat degradation or to the effectiveness of restoration programmes is generally one of the objectives of environmental monitoring and assessment programmes (Dauer et al. 1993). In the context of marine environments, studies focused on the benthos are considered to exhibit the greatest potential for revealing the environmental conditions in a site (Bilyard 1987, Gray

\footnotetext{
*E-mail: ggbpacas@lg.ehu.es
}

et al. 1990, Diaz 1992, Jan et al. 1994), with the community being the level of biological organization most popular for environmental studies (Clarke \& Green 1988, Smith et al. 1988, Underwood 1993, Warwick 1993). Specifically, the macrobenthos is the most widely used biotic component (Warwick 1993). At present, knowledge about the macrozoobenthic species in temperate coastal areas is large enough to guarantee their realistic use in environmental monitoring programmes (Warwick 1988a, Clarke \& Warwick 1994).

Of all the coastal habitats, those made up of rocks or coral reefs are the most densely inhabited by macroorganisms (Sebens 1985, Jan et al. 1994). Moreover, a 
growing interest has been recently shown in the use of the structure of sublittoral benthic communities on hard substrata for ecological monitoring (Kluijver \& Leewis 1994). However, subtidal, sessile, hard-substrata epibiota cannot be studied easily by the standard quantitative methods applicable to soft bottoms. Quantification of rocky communities may be done using biomass measurements (Hatcher 1995). Moreover, the use of biomass values has been accepted as a more objective measure of community structure, in comparison with abundance countings or coverage estimates, since it represents an estimate of the quantity of living substance in organisms (Warwick 1993, Clarke \& Warwick 1994, Palmerini \& Bianchi 1994). This approach is more appropriate when pollution gradients have to be considered (Warwick 1988a) and closer to the concept of energy-flow through the different compartments of a community (Brower \& Zar 1984, McQuaid \& Branch 1984).

The main goal in designing environmental impact studies for rocky habitats may be the development of more cost-effective monitoring strategies. In order to reduce the effort and increase the efficiency of monitoring programmes, analyses may be based upon reduced data sets, either using indicator organisms (see, for example, Bellan 1984, Reish 1986, Soule \& Kleppel 1988) or by using taxonomic units higher than species (see, for example, Heip et al. 1988, Warwick 1988a,b, Ferraro \& Cole 1990, Gray et al. 1990, Somerfield \& Clarke 1995, Olsgard et al. 1997, Chapman 1998).

It seems evident today that the concept of taxonomic sufficiency (Ellis 1985) has gained many supporters. In most monitoring programmes, identifying organisms only to the taxonomic level necessary and sufficient to meet a study's objectives is required. Hence, identifying animals or plants to the level of species is not always necessary, since many species may be interchangeable in the way these species characterize the samples (Clarke \& Warwick 1998). In addition, certain theoretical and practical advantages have been described for the use of taxonomic aggregation levels higher than species (Clarke \& Warwick 1994). With regard to hard bottom assemblages, the existence of taxonomic redundancy has been previously suggested for other localities on the North coast of the Iberian Peninsula (Juanes \& Canteras 1995) as well as for the area studied here (Urkiaga-Alberdi et al. 1999, PagolaCarte \& Saiz-Salinas 2000). Frequently, additional information is obtained if the taxonomic approach is also complemented by certain other criteria such as size classes (see, for example, Schwinghamer 1981, Warwick 1984), trophic groups (see, for example, Roth \& Wilson 1998), ecological guilds (see, for example, Sale \& Guy 1992) or even morphological similarity of organisms (Hatcher 1995).
Pilot studies are often time-consuming but generally considered a critical beginning in ecological research (Chapman 1998, Glasby 1998, and references therein). The main conclusion of a pilot study carried out in 1997 in the man-altered 'Abra de Bilbao' bay, was the final recommendation that subsequent monitoring programmes should focus on both the subtidal zone and taxonomically aggregated biomass measures of the biota, as little loss of information was noted (Pagola-Carte \& Saiz-Salinas 2000). All this would allow more efforts to be concentrated on obtaining further information from additional replicates or even from new sampling sites. In 1998 a second sampling survey was developed in the sublittoral zone of the investigated area, taking into account the recommendations indicated, with the purpose of increasing the efficiency of the monitoring programme. The present paper constitutes the results of that study. As the 'Abra de Bilbao' is a sort of semienclosed embayment with a river discharge in its innermost part, the main spatial pattern of the biotic responses was expected to be located along the longitudinal axis of the bay towards the open sea. In this context, the main objectives are: (1) to record the spatial differences in sublittoral hard substrate communities of the 'Abra de Bilbao' bay and adjacent rocky coast by using biomass measures; (2) to describe and quantify the importance of macrozoobenthic biomass, both by means of its own ecological value and in relation to the autotrophic compartment of the benthos (algae); (3) to test new criteria and to explore different levels of data aggregation, in order to determine the extent of biological redundancy accumulated on these rocky shore communities.

\section{MATERIAL AND METHODS}

Study area. The 'Abra de Bilbao' is a semi-enclosed bay located close to the mouth of the Nervión River on the Bay of Biscay, on the North coast of the Iberian Peninsula $\left(43^{\circ} 20^{\prime} \mathrm{N}, 3^{\circ} 01^{\prime} \mathrm{W}\right)$. Tides are semidiurnal with a maximum amplitude of about $4.5 \mathrm{~m}$. The greatest depth is about $30 \mathrm{~m}$. On the left bank is located the Port of Bilbao, which is now enlarging its facilities. Along the right side of the 'Abra de Bilbao', a long cliff drops towards the sea, although there are also several human constructions in the innermost part. The tidal part of the Nervión River has for many decades been subjected to an enormous loading of untreated sanitary sewage plus other industrial effluents (see Table 1). The pollutants which most adversely impact receiving waters within the bay include organic suspended solids and industrial waste (Gorostiaga \& Díez 1996). Benthic communities are made up almost exclusively of marine organisms since the Nervión River discharge affects 
Table 1. Summary of environmental variables measured in the 'Abra de Bilbao' bay. The minimum, the maximum and the mean value with its standard deviation for each water and sediment parameter is listed. The measurement units are indicated in parentheses. Metals include the summed concentrations for: cadmium, chromium, copper, lead, manganese, nickel, arsenium, selenium and zinc. NTU $=$ nephelometric turbidity units; TSS $=$ total suspended solids; wse $=$ water speed equivalents; $\mathrm{k}=$ extinction coefficient

\begin{tabular}{|c|c|c|c|}
\hline Parameters (units) & Minimum & Mean \pm SD & Maximum \\
\hline \multicolumn{4}{|l|}{ Water parameters } \\
\hline $\mathrm{NTU}_{\text {bottom }}(\mathrm{NTU})^{\mathrm{a}}$ & 1.43 & $2.13 \pm 0.55$ & 3.13 \\
\hline NTU $_{\text {surface }}(\mathrm{NTU})^{\mathrm{a}}$ & 0.96 & $2.14 \pm 1.00$ & 3.62 \\
\hline Salinity bottom $(\mathrm{psu})^{\mathrm{a}}$ & 33.60 & $34.2 \pm 0.33$ & 34.60 \\
\hline Salinity surface $(\mathrm{psu})^{\mathrm{a}}$ & 30.80 & $32.66 \pm 1.29$ & 34.40 \\
\hline $\mathrm{TSS}_{\text {bottom }}\left(\mathrm{mg} \mathrm{l}^{-1}\right)^{\mathrm{a}}$ & 2.65 & $5.06 \pm 2.04$ & 8.32 \\
\hline $\operatorname{TSS}_{\text {surface }}\left(\mathrm{mg} \mathrm{l}^{-1}\right)^{\mathrm{a}}$ & 1.88 & $2.96 \pm 0.99$ & 4.14 \\
\hline Hydrodynamism (wse) $^{\mathrm{a}}$ & 10.10 & $20.7 \pm 8.72$ & 33.70 \\
\hline Dissolved oxygen $\left(\mathrm{mg} \mathrm{l}^{-1}\right)^{\mathrm{a}}$ & 4.96 & $6.17 \pm 0.86$ & 7.30 \\
\hline Light $\left(\mathrm{k} \mathrm{in} \mathrm{m}^{-1}\right)^{\mathrm{a}}$ & 0.28 & $0.45 \pm 0.15$ & 0.73 \\
\hline Total coliform bacteria (CFU/100) $)^{\mathrm{b}}$ & 10 & $176674 \pm 487445$ & 2230000 \\
\hline Faecal coliform bacteria (CFU/100) ${ }^{\mathrm{b}}$ & 1 & $25712 \pm 66030$ & 269000 \\
\hline Faecal streptococcal bacteria (CFU/100) & )$^{\mathrm{b}} \quad 0$ & $4104 \pm 7807$ & 32000 \\
\hline \multicolumn{4}{|l|}{ Sediment parameters } \\
\hline Sedimentation $\left(\mathrm{g} \mathrm{m}^{-2} \mathrm{~d}^{-1}\right)^{\mathrm{a}}$ & 31.10 & $881.17 \pm 1191.72$ & 3411.00 \\
\hline Total organic carbon $(\%)^{\mathrm{c}}$ & 0.74 & $4.83 \pm 3.72$ & 9.44 \\
\hline Total organic nitrogen $(\%)^{\mathrm{c}}$ & 0.01 & $0.07 \pm 0.06$ & 0.15 \\
\hline Fines $<63 \mathrm{~mm}(\%)^{\mathrm{c}}$ & 2.4 & $44.93 \pm 40.98$ & 97.6 \\
\hline Metals $(\mathrm{ppm})^{\mathrm{c}}$ & 1148.29 & $1376.96 \pm 261.15$ & 1714.93 \\
\hline
\end{tabular}

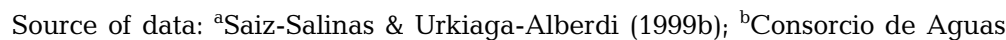
Bilbao-Bizkaia (1999); ${ }^{\circ}$ Consorcio de Aguas Comarca del Gran Bilbao (1996)
Concerning the present study, a total of 11 sampling stations were selected (Fig. 1). Eight were inside the 'Abra de Bilbao', the remaining 3 on the coastline outside it. Among them, Kobaron (Stn $\mathrm{K}$ ) is regarded as the reference or control station, since waters coming from the Nervión River are transported eastward by currents and, therefore, it is not affected (Orive 1989, Gorostiaga \& Díez 1996).

Sampling and processing. In summer 1998, sublittoral destructive samples were obtained from each of the 11 stations. They were collected at $5 \mathrm{~m}$ depth (below 0 tide level) using SCUBA. In all cases horizontal, photophilous surfaces on hard substrata were chosen and 3 replicates of $0.04 \mathrm{~m}^{2}(20 \times 20 \mathrm{~cm}$ quadrats $)$ were scraped off (Villalba \& Viéitez 1985, Ambrogi et al. 1988, Rallo et al. 1988, Hatcher 1995). All the macrobenthic components were placed in plastic bags and transported to the laboratory. Later on, bag contents were frozen to await processing, since freezing mainly surface waters due to a strong stratification of water masses along the bay (Rallo et al. 1988). By contrast, the amount of suspended particles introduced from the river mouth and the resulting high turbidity and sedimentation levels have been claimed as determining factors in the simplification of such communities (Rallo et al. 1988, Saiz-Salinas \& Isasi-Urdangarin 1994, Gorostiaga \& Díez 1996, Saiz-Salinas \& Urkiaga-Alberdi 1997, 1999a,b). Decreases in loading of several pollutants to the estuary are attributed to the general recession of the classical industry and to the better sewage treatment practices developed during the last 15 years. With the start-up of primary treatment in 1990, approximately $12400 \mathrm{~kg} \mathrm{~d}^{-1}$ of total suspended solids were removed from domestic sewage loading into the estuary (Gorostiaga \& Díez 1996), a feature which could help the bay to recover some algal species in locations where they were previously absent.

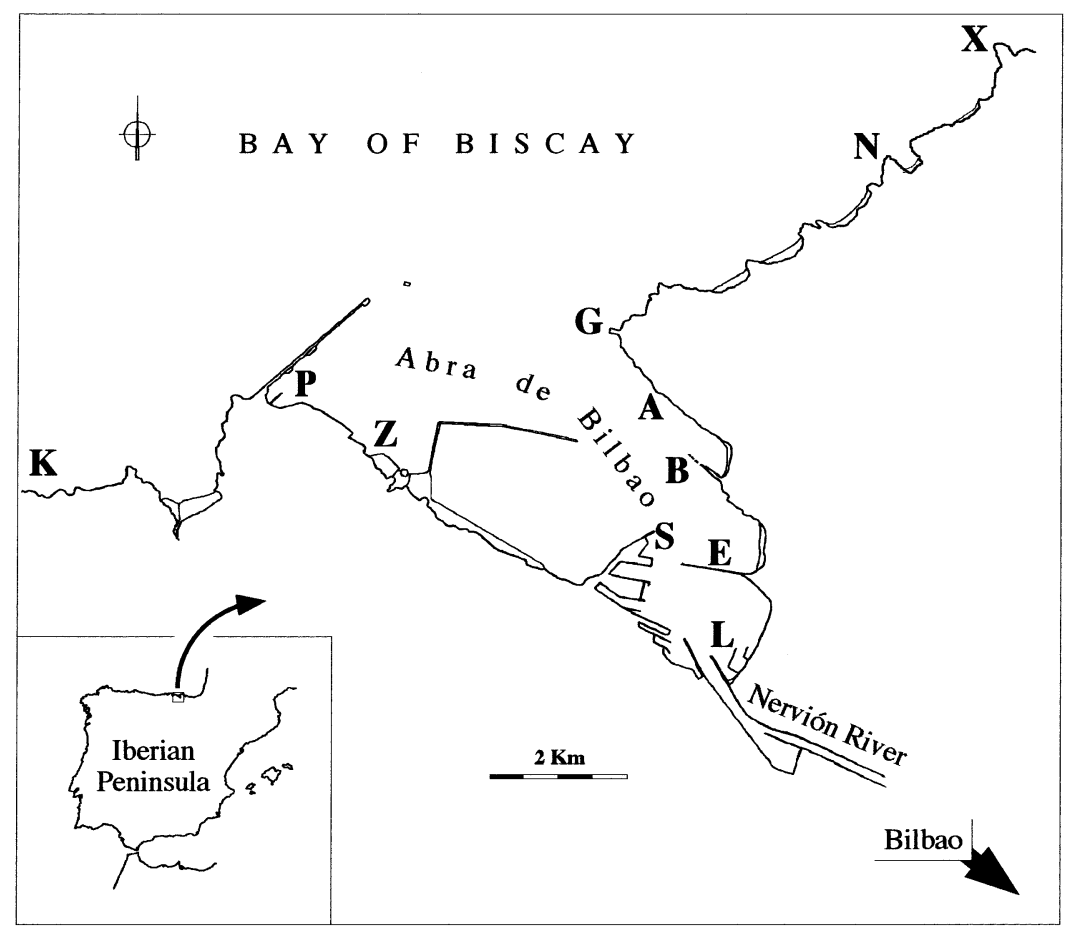

Fig. 1. The study area 'Abra de Bilbao' showing the sampling stations: K, Kobaron (= reference site); P, Punta Lucero; Z, Zierbena; S, Santurtzi; L, Las Arenas; E, Ereaga; B, Abasotas; A, Arrigunaga; G, Punta Galea; N, Meñakoz; X, Matxilando 
is recommended rather than chemical preservation as a method of storage for subsequent biomass measurements (Hatcher 1995, 1997, Ricciardi \& Bourget 1998). Additional qualitative samples of certain species were collected to verify taxonomic identities in the laboratory.

During the processing, samples were sieved through a $0.5 \mathrm{~mm}$ mesh screen. Separation of macrofauna was done to different aggregation levels, as described below. Macroflora were considered as a whole with the purpose of recording a single basic measurement of autotrophic biomass. Weight determinations of each sorted component were taken as ash free dry weight (AFDW). Initially, dry weights (DW) were obtained after desiccation in a oven at $100^{\circ} \mathrm{C}$ for $10 \mathrm{~h}$. Ash weights (AW) of the same fractions were measured after incineration in a muffle furnace at $450^{\circ} \mathrm{C}$ for $10 \mathrm{~h}$. AFDW values were obtained by subtracting DW - AW.

Biotic data aggregation: several criteria. In order to fulfill the third of the objectives proposed, macrofauna separation was carried out to several aggregation levels and according to different criteria. Organisms were not quantified at species level, with the exception of 2 large-size bivalve species, Mytilus galloprovincialis and Ostrea edulis, which exhibited the greatest biomass values. A procedure involving biomass quantification at species level is not always necessary and even is highly time-consuming (see 'Introduction'). Nevertheless, species were identified (without any type of quantification) in order to obtain one of the diversity measures (total number of species, $S$ ). Due to the sampling methods employed, members belonging to Porifera and Hydrozoa had to be excluded from the species identifications.

The first criterion applied was taxonomic, by which biomass data of the samples were pooled into phyla. The second criterion was functional, with 2 different choices: aggregation by trophic groups and aggregation by what we called trophic 'metagroups'. Identified trophic groups included primary producers, suspension feeders, herbivores, carnivores, detritivores, and omnivores. Only 3 trophic metagroups were defined: primary producers, suspension feeders and 'others', since algae and suspension feeders were considered the main types among the various trophic strategies recorded on the 'Abra de Bilbao' hard bottoms. Furthermore, a fauna/flora biomass matrix was also constructed. As a result of the combination of both criteria (taxonomic and trophic), there were cases in which a more exhaustive taxonomic sorting was needed (cases in which a single trophic behaviour could not be attributed to a phylum). We searched for the minimal number of taxa needed to fulfill both criteria, which resulted in 29 mixed taxa (phyla, classes, orders and sometimes species), including 2 bivalve species, re- garded as different from other bivalves due to their great biomass contribution (Ostrea edulis and Mytilus galloprovincialis). Hence, the sorting procedure was reduced to those 29 'minimal taxa' plus the algal fraction, although a recording of all the species present in the samples was carried out, as mentioned above.

The fourth, practical criterion was applied a posteriori to the complete data set of minimal taxa. According to the field and laboratory experience, 17 high-level taxonomic taxa were subjectively proposed ('proposed taxa'), which were never under the category of suborder and could be easily identified and sorted. Also, 13 taxa were directly selected from the minimal taxa, under the condition of accounting for more than $1 \%$ of the average biomass along the 11 stations ('high biomass taxa'). All the analyses were carried out on the basis of the 8 data sets obtained, according to a progressive order of simplification in the number of organism groupings: 1, Minimal taxa (+algae); 2, Minimal taxa; 3, High biomass taxa; 4, Proposed taxa; 5, Phyla; 6, Trophic groups; 7. Trophic metagroups; 8, Fauna/Flora. A scheme of all the organisms regarded within each level and of the correspondences between them appears in Table 2 .

Analysis of data. For each replicate and sampling site, several biomass-related parameters and indices were calculated: total macrofaunal biomass (A), total macrofloral biomass (V), total assemblage biomass (B), the ratio macrofauna/macroflora $(\mathrm{A} / \mathrm{V}$, indicative of whether autotrophic or heterotrophic dominance) and the ratio of dry weight/ash free dry weight (D/A, indicative of the assemblage's investment in calcified structures). Also, a number of diversity-related indices were obtained for each replicate and sampling site: total number of species $(S)$, Hill's first and second numbers $\left(N_{1}\right.$ and $N_{2}$ diversities), evenness $\left(J^{\prime}\right)$ calculated as $H^{\prime}-H_{\text {max }}^{\prime}$ and Margalef's richness $(d)$. With the exception of the last index, the unifying system for diversity and evenness of Hill (1973) was adopted. The DIVERSE program of the computer software package PRIMER was employed using logarithms to base 2. All the indices were based on the biomass figures of every aggregation level data set. Consequently, 'n' (abundance) in the formulae was replaced by biomass of the groups given in Table 2.

In order to record and interpret spatial patterns in the hard bottom assemblages from the area, multivariate analysis techniques were used. Biomass matrices of all the aggregation levels previously defined were employed in the routines of the computer software package PRIMER. Representation of communities was accomplished by classification and ordination techniques (Field et al. 1982, Clarke \& Green 1988, Gray et al. 1988, Clarke 1993, Clarke \& Warwick 1994) based on Bray-Curtis and $\log (y+1)$ transformed dissimilarity matrices of biomass mean values. Classification of stations by hierarchical 


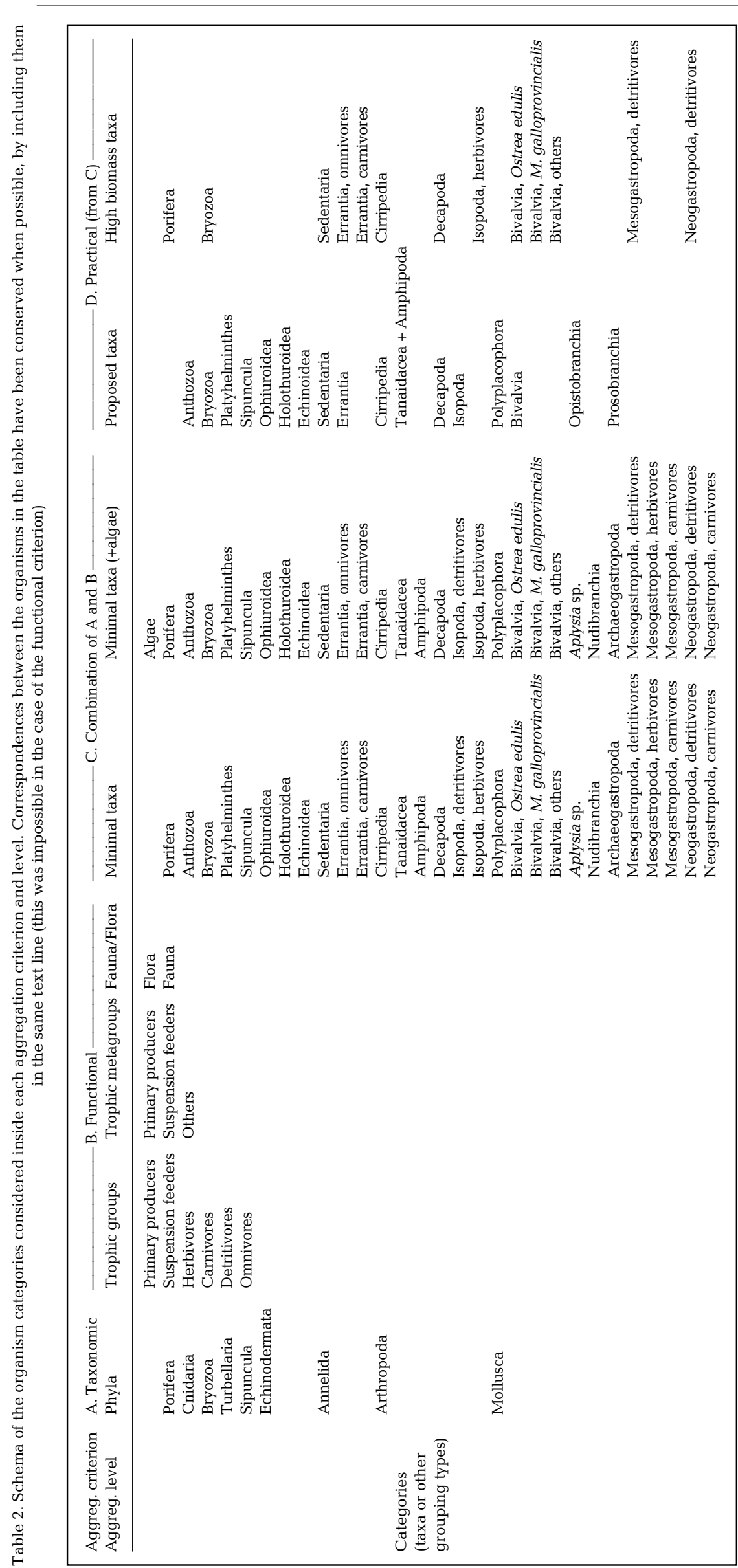

agglomerative clustering (groupaverage linking CLUSTER) was followed by non-metric multidimensional scaling (MDS) as an ordination method. This representation of the biotic pattern among stations was carried out using all the aggregation levels mentioned above. The indicator organisms which most contributed to the differences observed among the assemblages sampled were found out by means of the SIMPER program. This technique (Clarke 1993) computes average dissimilarities between all pairs of inter-group samples, followed by computations of the contributions of each taxon, giving standard deviations for the values, as a measure of how consistently a species contributes to the average dissimilarity.

\section{RESULTS}

\section{Community structure}

Biomass-related parameters derived from 11 sampling stations (Fig. 1) are shown in Fig. 2. The amount of living matter per surface unit (Fig. 2a) of the assemblages ranges from $193 \mathrm{~g}$ AFDW m ${ }^{-2}$ (Stn G) to $2883 \mathrm{~g} \mathrm{AFDW}^{-}$ $\mathrm{m}^{-2}$ (Stn E). Hence, the major differences are located within the 'Abra de Bilbao' (see Fig. 1). The reference site (Stn K) shows a medium to high value of total biomass (1682 $\mathrm{g}$ AFDW $\mathrm{m}^{-2}$ ), whereas the contribution of calcified structures to the overall (D/A index) is the lowest of any of the stations. The highest figures of D/A, by contrast, appear within the 'Abra de Bilbao', as occurred with parameter $B$. On the other hand, readily apparent is the existence of a sharp pattern of increasing total biomass towards the central part of the area, where the maximum value, mentioned, above, is reached at Stn E.

A more detailed approach is obtained by considering the relative importance of macrofauna and macroflora components as a whole. Fig. 2b shows the weight of the animal and 

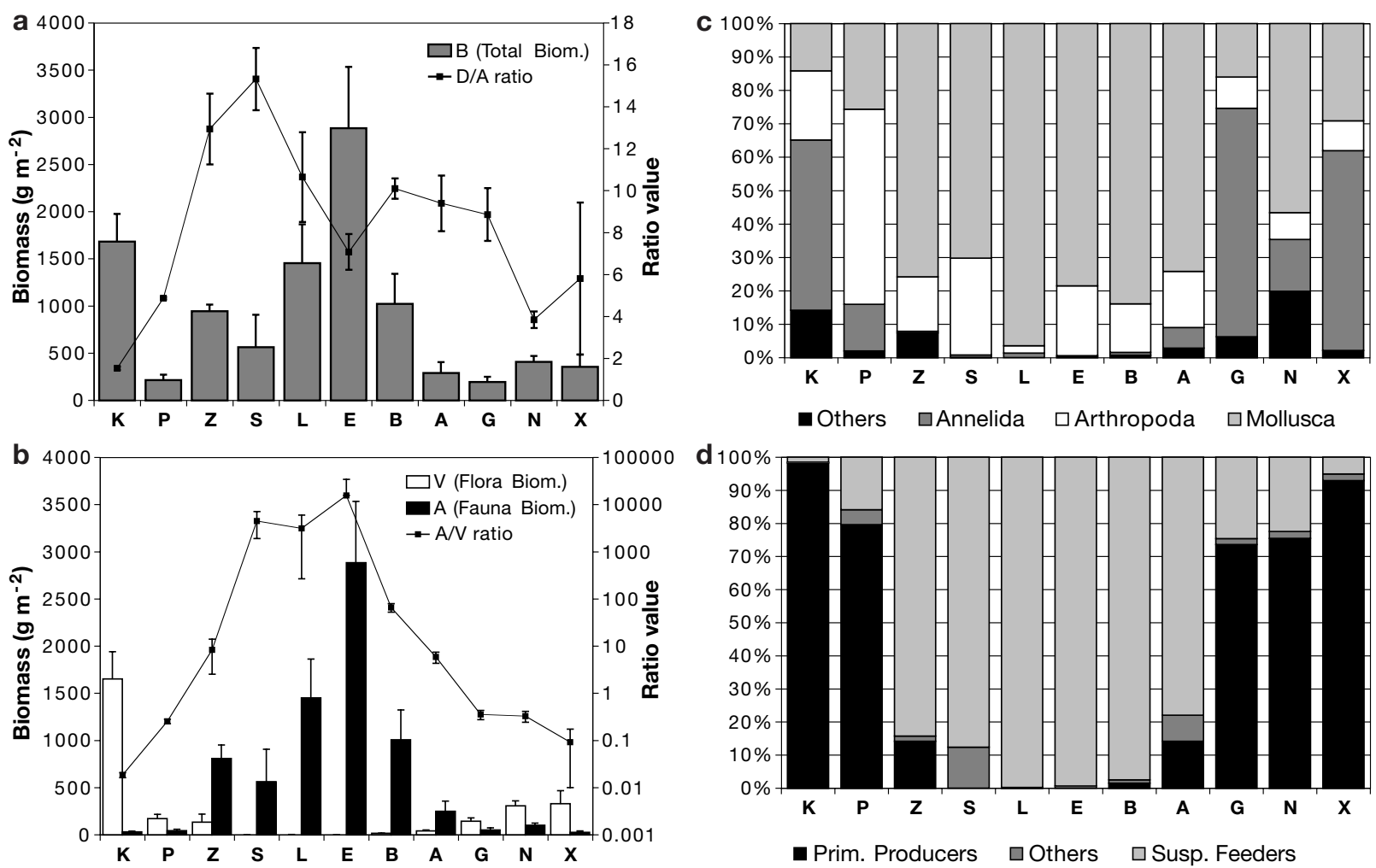

Fig. 2. Biomass-related parameters for each station: (a) Total biomass (B) and the ratio dry weight/ash free dry weight (D/A), indicative of the assemblage's investment in calcified structures. (b) Flora and fauna biomass (V and A) and the ratio A/V computed from them, indicative of whether there is autotrophic or heterotrophic dominance. (c) Proportions in terms of biomass of the phyla recorded. (d) Proportions in terms of biomass of the trophic groups recorded. Stations from west to east (Fig. 1) are presented in the graphs from left to right in the same order. Error bars represent standard deviations

algal fractions at each assemblage, as well as the ratio A/V. Another spatial pattern is observed along this plot, which follows the same trend as that described by the total biomass curve. In contrast with the previous recorded sampling site arrangement, however, in this case, the curve is clearly expanded to the outermost sampling sites. Algae become relevant at the 2 extremes of the adjacent coast area, outside the 'Abra de Bilbao'. Within the bay, animals account for most of the biomass. In general, the dominance of macrofauna $(\mathrm{A} / \mathrm{V})$ is seen to be somewhat related to a high production of calcified structures (D/A), as can be inferred from direct comparison between the 2 curves. Nevertheless, at the innermost stations (Stns L and E), calcified structures decrease, indicating certain differences within the faunal component.

A total of 107 macrofauna species were identified: Mollusca, 36 (33.6\%); Arthropoda (Crustacea), 35 (32.7\%); Annelida (Polychaeta), 18 (16.8\%); Bryozoa, $7(6.5 \%)$; Echinodermata, $5(4.6 \%)$; Cnidaria (Anthozoa), $3(2.8 \%)$; Sipuncula, 2 (1.8\%); Platyhelminthes, $1(1.9 \%)$. Mollusca were the dominant phylum at almost all the stations, followed by Arthropoda (Crustacea) and Annelida (Polychaeta) (Fig. 2c). According to the classification into the feeding groups established, primary producers and suspension feeders account for the majority of the benthic biomass of the 'Abra de Bilbao' and adjacent waters (Fig. 2d). Among the animals, the detritivorous strategy is noteworthy at Santurtzi Stn (S), whereas a relative higher trophic diversity is a characteristic of Stn Arrigunaga (A).

The different indices of diversity agree in general (Fig. 3). They present, once more, a clear spatial pattern in the distribution of benthic biomass along the studied sites. Central stations show the lowest values of diversity (Hill's $N_{1}$ and $N_{2}$, and Margalef's index) and equitability ( $J^{\prime}$ evenness), in contrast with the more marine influenced, algae-dominated outer stations. In the case of $N_{2}$ (the reciprocal of Simpson's dominance index), by using trophic data, both Stn K and the group formed by Stns L, E and B are very close to the lowest value of 1 (total dominance). Furthermore, in the case of Stn L, other taxonomic data (e.g. phyla) produce very similar results, due to the strong predominance of molluscs at this station (see Fig. 2c). The visual effect of displaying diversity values for each of the aggregation levels in the same plots has the additional advantage of indicating new aspects of the assemblages. In fact, the 

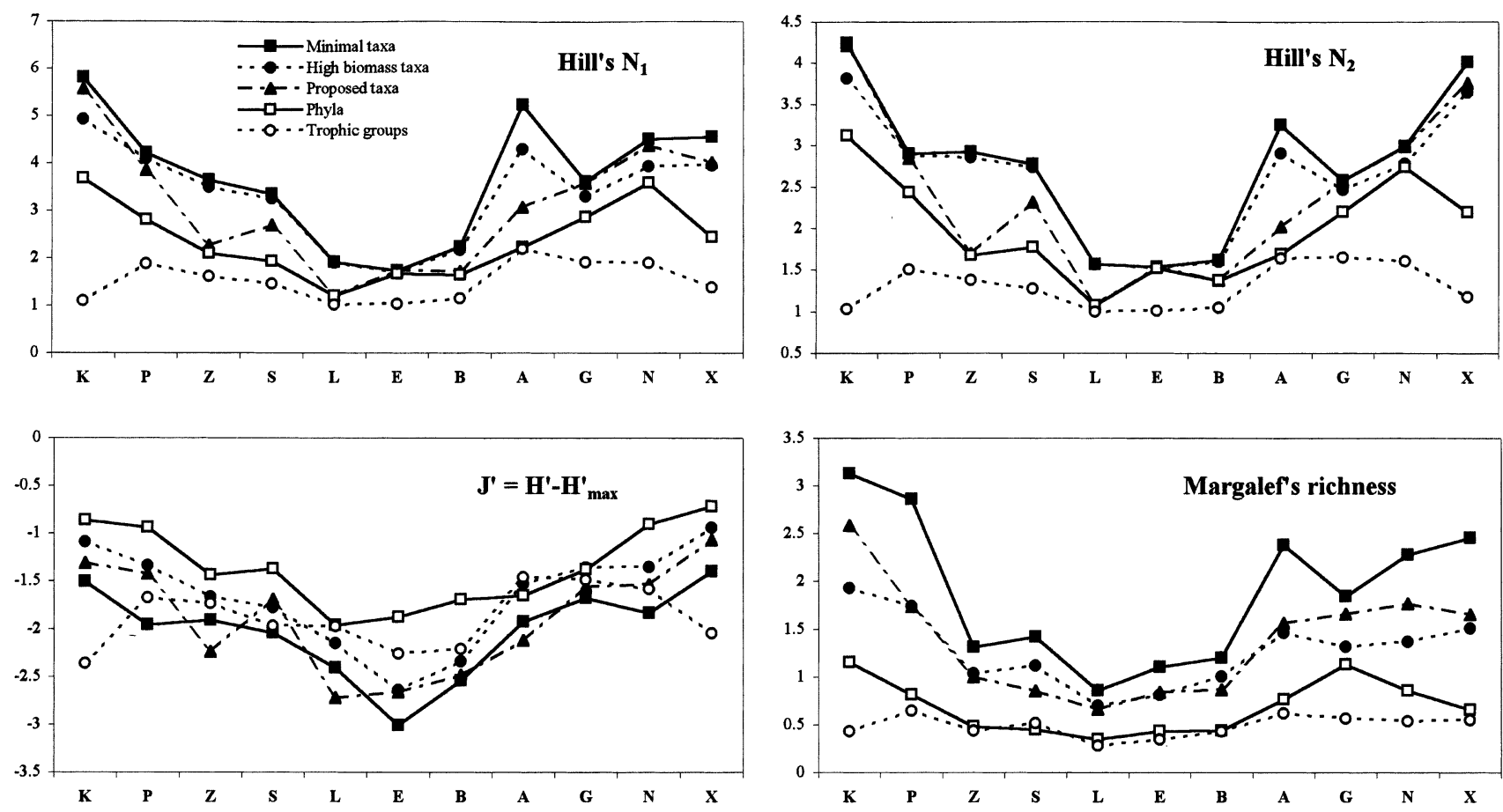

Fig. 3. Diversity-related parameters obtained for each station based on biomass measurements: Hill's first and second numbers ( $N_{1}$ and $N_{2}$ diversities), evenness $\left(J^{\prime}\right)$ calculated as $H^{\prime}-H^{\prime}$ max , and Margalef's richness $(d)$. Only the most informative aggregation levels are shown (from minimal taxa to trophic groups). The order of the stations is the same as in the previous figure

representation of trophic group diversity shows that the 'innermost' and 'outermost' areas are less trophically diverse, due to animal or algal dominance respectively. This leads us to consider the intermediate stations (Stns P, Z and A) as the most trophically diverse, although macrofaunal diversity tends to be the greatest towards the outermost (most marine-like) areas. On the other hand, the Arrigunaga (A) sampling station, in spite of being located within the 'Abra de Bilbao', proved to be an outstanding location, both in terms of taxonomic and trophic diversity. This feature is better shown by Hill's $N_{1}$ and $N_{2}$.

\section{Analysis of spatial differences}

Bidimensional representations of the MDS ordination analysis are shown in Fig. 4. Two obvious groups or clusters of stations are segregated along the first $5 \mathrm{ag}$ gregation levels employed: on the one hand, Stns Z, S, L, E, B and A, which form a clear grouping on the left side of the MDS; and on the other hand, Stns K, P, G, N and $\mathrm{X}$, which integrate a quite scattered grouping on the right side. These 2 clusters can be geographically separated on the map (see Fig. 1), i.e. they represent 2 poles of the already mentioned 'inner-outer sites' axis, which is somewhat linked to the direction of the Nervión River discharge. MDS representations pro- duce a rather different arrangement of the stations when the functional criterion is applied. In fact, the last 3 analyses display the sampling stations in 3 separated groups. The one formed by the outer stations (Stns K, $\mathrm{P}$, G, N and $X$ ) is again maintained, while the remaining stations are grouped into a pair of new clusters: the innermost stations (Stns S, L and E) versus intermediate stations (Stns Z, B and A). These intermediate stations, however, appear more closely related to the outermost stations than to the innermost ones. All the MDS plots are associated with values of stress that fall into the categories of 'excellent' representation or (in the case of proposed taxa) of 'good' ordination (Clarke 1993).

Table 3 shows the results of SIMPER analysis for each aggregation level. We were seeking dissimilarities between the clusters of stations previously established in the ordination plots (Fig. 4). Accordingly, 3 types of intercluster combinations are possible under the functional criterion of trophic groups and metagroups. If minimal taxa are considered, the most outstanding feature is the importance of 2 bivalve species (Ostrea edulis and Mytilus galloprovincialis). These are responsible for a great amount of the dissimilarity, in terms of biomass, between the outer and the inner groups of sampling sites. The inclusion or exclusion of algae in this level of analysis (thus regarding all the species of algae as a minimal taxon) was insignificant in the ordination of the sites, while they appear 


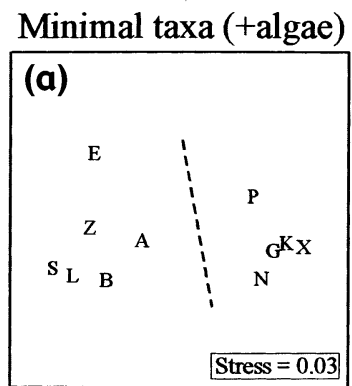

Phyla

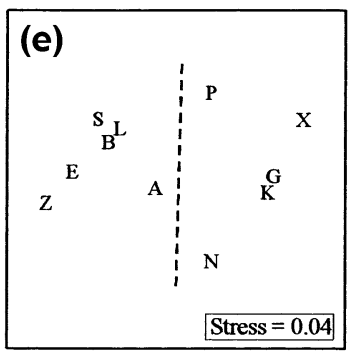

Minimal taxa

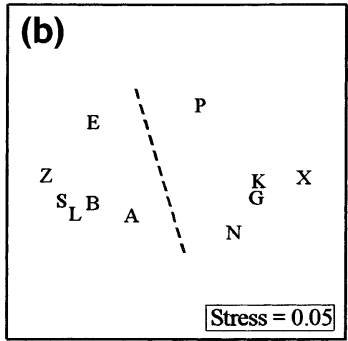

Trophic groups

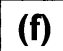

(f)

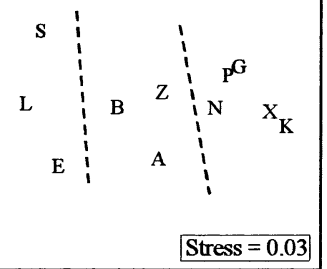

High biomass taxa

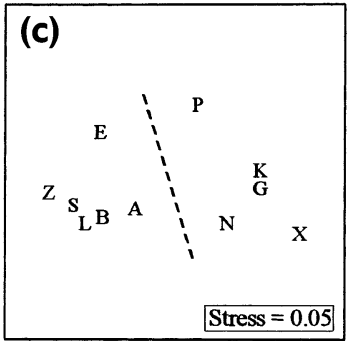

Trophic metagroups

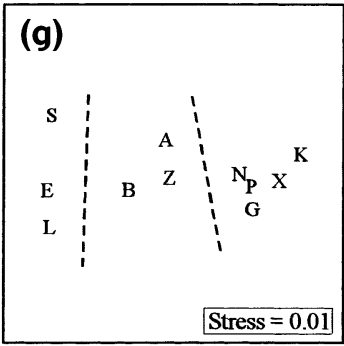

Proposed taxa

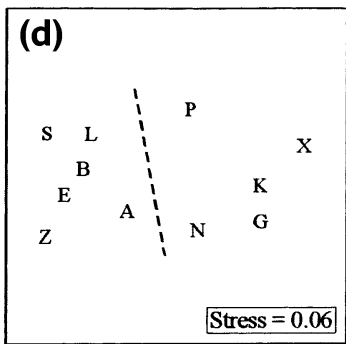

Fauna / Flora

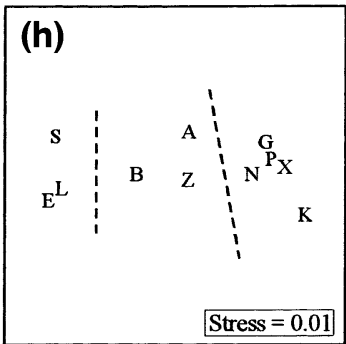

Fig. 4. MDS plots obtained after ordination of the stations based on the biomass measurements of the organisms sampled. The 8 cases presented correspond to the following aggregation levels, described in the text: (a) minimal taxa, considering algae as a whole; (b) minimal macrofaunal taxa; (c) high biomass (>1\%) taxa; (d) subjectively proposed taxa; (e) phyla; (f) trophic groups; (g) trophic 'metagroups'; (h) fauna/flora. Stress values of the MDSs are also given

strongly involved in the similarity among stations. Other bivalves, as well as some detritivorous gastropods (belonging to the genus Hinia), are also responsible for differences observed, but less than Cirripedia. Other relevant taxa are the bryozoans, sedentary polychaeta and anthozoans. It can be said that the results of the remaining aggregation levels are basically the same, with some degree of progressive simplification. This fact points towards the idea of a coherent, inclusive model of aggregation in the processing and treatment of data. However, some points deserve to be further considered.

First, Mollusca and Arthropoda (Crustacea), apart from being the phyla with the highest biomass in the area studied (see Fig. 2c), are very sensitive in separating the types of assemblages found, since they contribute largely to site groupings. Moreover, at the 'high biomass taxa' level, 5 taxa belonging to these 2 phyla account between them for $75 \%$ of the cumulative dissimilarity $\left(\mathrm{Cum}_{\mathrm{i}} \%\right)$. Second, the analysis performed by using the subjectively proposed taxa is less dependent on the aforementioned organisms and includes some other taxa, such as Bryozoa, Sedentaria, Anthozoa and Porifera. Finally, a different perspective is acquired when a trophic point of view is considered. In fact, the rearrangement of organisms into these new, functional categories resulted in a 3-cluster organization, which is explained by the biomass values provided from the different feeding strategies. The most marine-like stations (Stns K, P, G, N and X) are separated from the rest mainly due to primary producers and suspension feeders, based more significantly on primary producers when comparing with the innermost stations (Stns S, L and E) and on suspension feeders when dealing with the intermediate ones (Stns Z, B and $\mathrm{A}$ ). On the other hand, dissimilarities between innermost and intermediate sites are mainly due to primary producers and other types of trophic strategies (detritivores, omnivores and suspension feeders, to a similar extent). Summarizing, the clusters of stations obtained under this functional criterion are an indication of the prevalent trophic status of the assemblages' species. Thus, in the case of the innermost sites of the area studied they are represented by suspension feeders. In the most external or open-sea stations, algae are the most important component in terms of biomass; and in the intermediate zone of the 'Abra de Bilbao', the main characteristic is a mixture of both suspension feeders and algae. Moreover, macrofauna other than suspension feeders are capable of delimiting differences among the sites located within the 'Abra de Bilbao', as is the case for the detritivores or the omnivores.

\section{DISCUSSION}

The study of the community structure on rocky surfaces of the 'Abra de Bilbao' by means of univariate 
Table 3. Results of SIMPER analysis on each aggregation level. Taxa are ranked according to their average contribution $\left(\delta_{i}\right)$ to dissimilarity between groups. The values of standard deviation $\left(\mathrm{SD}\left(\delta_{\mathrm{i}}\right)\right)$, the ratio $\delta_{\mathrm{i}} / \mathrm{SD}\left(\delta_{\mathrm{i}}\right)$, and the percentage of cumulative dissimilarity $\left(\mathrm{Cum} \delta_{\mathrm{i}} \%\right)$ are also given. In the cases of trophic groups and metagroups, similarities are calculated between 3 pairs of station groups (and not 2 as in the other levels), since 3 clusters were obtained after the classification analysis

\begin{tabular}{|c|c|c|c|c|}
\hline & $\delta_{\mathrm{i}}$ & $\mathrm{SD}\left(\delta_{\mathrm{i}}\right)$ & $\delta_{\mathrm{i}} / \mathrm{SD}\left(\delta_{\mathrm{i}}\right)$ & $\operatorname{Cum} \delta_{\mathrm{i}} \%$ \\
\hline \multicolumn{5}{|c|}{ Aggregation level: Minimal taxa (+Algae) } \\
\hline \multicolumn{5}{|c|}{ [Groups $(K, P, G, N, X)$ vs $(Z, S, L, E, B, A)]$} \\
\hline Bivalvia, O. edulis & 11.14 & 3.43 & 3.25 & 18.91 \\
\hline Bivalvia, M. galloprovincialis & 9.65 & 5.48 & 1.76 & 35.30 \\
\hline Algae & 8.12 & 4.86 & 1.67 & 49.08 \\
\hline Cirripedia & 6.23 & 3.16 & 1.97 & 59.66 \\
\hline Neogastropoda, detritivores & 3.62 & 2.57 & 1.41 & 65.81 \\
\hline Bivalvia, others & 2.56 & 1.80 & 1.42 & 70.16 \\
\hline Bryozoa & 2.24 & 2.33 & 0.96 & 73.97 \\
\hline Sedentaria & 1.79 & 1.27 & 1.41 & 77.00 \\
\hline \multicolumn{5}{|c|}{ Aggregation level: Minimal taxa } \\
\hline \multicolumn{5}{|c|}{ [Groups $(K, P, G, N, X)$ vs $(Z, S, L, E, B, A)]$} \\
\hline Bivalvia, O. edulis & 13.27 & 3.87 & 3.43 & 21.83 \\
\hline Bivalvia, M. galloprovincialis & 11.61 & 6.56 & 1.77 & 40.92 \\
\hline Cirripedia & 7.45 & 3.73 & 2.00 & 53.17 \\
\hline Neogastropoda, detritivores & 4.30 & 2.97 & 1.45 & 60.24 \\
\hline Bivalvia, others & 3.07 & 2.15 & 1.43 & 65.29 \\
\hline Bryozoa & 2.71 & 2.88 & 0.94 & 69.74 \\
\hline Sedentaria & 2.15 & 2.07 & 1.04 & 73.28 \\
\hline Anthozoa & 2.14 & 1.51 & 1.42 & 76.79 \\
\hline \multicolumn{5}{|c|}{$\begin{array}{l}\text { Aggregation level: High biomass taxa } \\
{[\text { Groups }(K, P, G, N, X) \text { vs }(Z, S, L, E, B, A)]}\end{array}$} \\
\hline Bivalvia, O. edulis & 14.65 & 4.21 & 3.48 & 25.25 \\
\hline Bivalvia, M. galloprovincialis & 12.62 & 6.86 & 1.84 & 47.01 \\
\hline Cirripedia & 8.24 & 4.14 & 1.99 & 61.21 \\
\hline Neogastropoda, detritivores & 4.73 & 3.15 & 1.50 & 69.37 \\
\hline Bivalvia, others & 3.44 & 2.47 & 1.39 & 75.31 \\
\hline \multicolumn{5}{|c|}{$\begin{array}{l}\text { Aggregation level: Proposed taxa } \\
{[\text { Groups }(K, P, G, N, X) \text { vs }(Z, S, L, E, B, A)]}\end{array}$} \\
\hline Bivalvia & 13.31 & 4.82 & 2.76 & 28.71 \\
\hline Cirripedia & 8.85 & 4.25 & 2.08 & 47.82 \\
\hline Prosobranchia & 4.25 & 3.40 & 1.25 & 56.99 \\
\hline Bryozoa & 3.19 & 3.39 & 0.94 & 63.88 \\
\hline Sedentaria & 2.56 & 1.79 & 1.43 & 69.40 \\
\hline Anthozoa & 2.51 & 2.37 & 1.06 & 74.82 \\
\hline Porifera & 2.41 & 1.73 & 1.39 & 80.01 \\
\hline \multicolumn{5}{|c|}{$\begin{array}{l}\text { Aggregation level: Phyla } \\
{[\text { Groups }(K, P, G, N, X) \text { vs }(Z, S, L, E, B, A)]}\end{array}$} \\
\hline Mollusca & 15.99 & 5.31 & 3.01 & 38.46 \\
\hline Arthropoda & 10.41 & 4.75 & 2.19 & 63.49 \\
\hline Bryozoa & 4.04 & 4.25 & 0.95 & 73.19 \\
\hline Cnidaria & 3.22 & 3.04 & 1.06 & 80.93 \\
\hline \multicolumn{5}{|l|}{ Aggregation level: Trophic groups } \\
\hline Primary producers & 12.49 & 3.19 & 3.91 & 40.80 \\
\hline Detritivores & 3.99 & 3.56 & 1.12 & 53.82 \\
\hline Omnivores & 3.92 & 2.65 & 1.48 & 66.64 \\
\hline Suspension feeders & 3.84 & 2.36 & 1.63 & 79.19 \\
\hline \multicolumn{5}{|l|}{ [Groups $(S, L, E)$ vs $(K, P, G, N, X)]$} \\
\hline Primary producers & 22.28 & 3.44 & 6.48 & 44.30 \\
\hline Suspension feeders & 14.47 & 3.71 & 3.90 & 73.07 \\
\hline Detritivores & 6.07 & 5.28 & 1.15 & 85.15 \\
\hline \multicolumn{5}{|l|}{$[\operatorname{Groups}(\mathrm{Z}, \mathrm{B}, \mathrm{A})$ vs $(\mathrm{K}, \mathrm{P}, \mathrm{G}, \mathrm{N}, \mathrm{X})]$} \\
\hline Suspension feeders & 9.69 & 3.39 & 2.86 & 35.83 \\
\hline Primary producers & 7.12 & 4.56 & 1.56 & 62.17 \\
\hline Detritivores & 2.98 & 2.08 & 1.43 & 73.18 \\
\hline Herbivores & 2.74 & 2.45 & 1.12 & 83.33 \\
\hline \multicolumn{5}{|c|}{$\begin{array}{l}\text { Aggregation level: Trophic metagroups } \\
{[\text { Groups }(\mathrm{S}, \mathrm{L}, \mathrm{E}) \text { vs }(\mathrm{Z}, \mathrm{B}, \mathrm{A})]}\end{array}$} \\
\hline Primary producers & 14.53 & 3.41 & 4.26 & 60.93 \\
\hline Others & 4.70 & 2.85 & 1.65 & 80.64 \\
\hline \multicolumn{5}{|l|}{ [Groups $(S, L, E)$ vs $(K, P, G, N, X)]$} \\
\hline Primary producers & 24.74 & 3.51 & 7.05 & 52.95 \\
\hline Suspension feeders & 16.15 & 4.33 & 3.73 & 87.51 \\
\hline \multicolumn{5}{|l|}{$[\operatorname{Groups}(\mathrm{Z}, \mathrm{B}, \mathrm{A})$ vs $(\mathrm{K}, \mathrm{P}, \mathrm{G}, \mathrm{N}, \mathrm{X})]$} \\
\hline Suspension feeders & 11.12 & 3.67 & 3.03 & 49.20 \\
\hline Primary producers & 8.28 & 5.21 & 1.59 & 85.83 \\
\hline
\end{tabular}

measures has proved to be useful in characterizing different types of assemblages along the sublittoral zone of the area. Parameters such as the amount of living matter (biomass) per surface area or the differential contribution of fauna and flora to assemblages clearly reflect the gradient of environmental disturbance that is affecting the macrobenthos. Overall community biomass increases towards the most disturbed zone (innermost parts), due to the proliferation of microphagous animals, mainly suspension feeders with calcareous exoskeletons that form conspicuous beds (mussels, oysters and barnacles) on the hard bottoms. The lack of macroalgal dominance over photophilous bottoms has been discussed earlier for the investigated area, both intertidally (Saiz-Salinas \& Urkiaga-Alberdi 1997) and subtidally (Saiz-Salinas \& Isasi-Urdangarin 1994). The present study provides new data on fauna and flora biomass. In fact, the edge of the sea is a suitable habitat for plant growth in temperate latitudes, especially the sublittoral zone (Mann 1973). However, the success of suspension feeders in the 'Abra de Bilbao' bay is explained by a combination of modifying factors, such as suspended solids and wave exposure.

Suspended solids have 2 main contrasting effects on rocky communities. On the one hand, large amounts of suspended solids in the water column can cause physiological stress to algae, since turbidity reduces light availability for photosynthesis (Hartnoll 1983, Hiscock 1985, Rogers 1990; see for the study area Gorostiaga \& Díez 1996). On the other hand, suspended solids enriched with organic matter represent an important source of potential food for suspension feeders, as has been noted by Gili \& Coma (1998) on the basis of the optimal foraging theory. In this sense, the work of Navarro et al. (1996) on feeding mussels in closed systems is of particular interest. The best optimal nutritional conditions were obtained artificially with mixtures of phytoplankton and bottom sediments of 40:60 and 25:75 (microalgae:sediment). Increased absorption rates allow greater amounts of ingested food to be processed at greater efficiency and, as a final result, growth is enhanced. Nevertheless, it is necessary to note that excessive levels of turbidity (causing siltation) are known to be detrimental 
to many epibenthic species, either by smothering or clogging their feeding mechanisms (Gray 1979, Hiscock 1983; see for the study area: Saiz-Salinas \& IsasiUrdangarin 1994).

However, our findings are somewhat in contradiction with the expectations provided by models of dominance curves in stressed ecosystems using biomass measures (ABC model: Warwick 1986, Warwick et al. 1987). In these models, a stage with faunal biomass dominance (biomass dominated by a few species with large individuals in low numbers) is interpreted as non-stressed or unpolluted (Warwick 1986, McManus \& Pauly 1990). By contrast, the hard bottoms of the 'Abra de Bilbao' tend to accumulate large amounts of community biomass (due to large sized animals, mainly suspension feeders) in degraded places. It is remarkable to note that any other planned research which had considered exclusively the algal fraction without animals would have better matched the expected trend of increasing biomass dominance towards less stressed conditions (with very high values at the reference station). Indeed, the expectations of the ABC model have been criticized from theoretical positions (see the consideration of McManus \& Pauly 1990 about the model's assumption that communities generally tend towards an equilibrium). Moreover, its validity has been questioned by studies showing inadequate classifications of several sites in relation to their previously known ecological stress levels (see, for example, Dauer et al. 1993). According to Gray et al. (1988), the ABC model may be valid both for some classes of macrobenthic communities and stresses but not for others. In the case of the present study, data on abundance are lacking and, unfortunately, it has not been possible to perform such analyses to date. However, several points concerning biomass values from hard bottom communities can be positively sustained.

Two points should be considered in understanding the dynamics of the hard bottoms of the 'Abra de Bilbao': Firstly, the biomass dominance approach is sensitive to both human induced pollution and natural disturbance (Lardicci \& Rossi 1998). Secondly, the 2 well-defined macrobenthic components (algae and animals, mainly suspension feeders) represent the existence of 2 contrasting biotic strategies competing for the cover of the same space. Both features are probably behind the observed pattern, weakening the utility of the biomass dominance approach of the ABC technique. A different approach including the main factors affecting hard substrate communities in the 'Abra de Bilbao' is needed in order to understand all the mechanisms involved.

The great amount of suspended solids and the associated turbidity play a fundamental role in determining whether fauna or flora are dominant, as has already been discussed (but see also Mettam 1994, Gabriele et al. 1999). In addition, the presence and abundance of suspension feeders on hard substrata has been highly correlated with wave exposure (for the intertidal zone, Ricciardi \& Bourget 1999 present a complete review). Accordingly, we propose that a combination of both factors (turbidity and exposure) would explain the spatial distribution of total benthic biomass and its animal or vegetal nature in the subtidal conditions of the 'Abra de Bilbao'. Wave exposure is particularly relevant along the whole area investigated (Gorostiaga \& Díez 1996) with lower effects at the innermost part of the bay, where the river mouth is located. Its water discharge mainly affects the inner part of the bay, although a lesser influence has been noted towards the open sea (Rallo et al. 1988). On that basis, suspended solids constitute the prevailing stressing factor at the innermost sites of the 'Abra de Bilbao' and their effect is superimposed on wave exposure at the rest, with a decreasing influence towards the 2 outermost areas investigated. Suspension feeders are known to be promoted by strong water movement, a feature which provides larger food supply and prevents the negative effects of excessive turbidity mentioned above (Hartnoll 1983, Hiscock 1983, Kluijver 1993, Hily \& Jean 1997, Ricciardi \& Bourget 1999). In addition, sheltered zones in temperate coasts are usually dominated by macroalgae, in the form of a continuous cover or canopy that may occur from the high shore to the sublittoral zone (Hiscock 1985, Norton 1985, Jenkins et al. 1999). These considerations would lead to a distribution of faunal biomass different from that found in this study. However, turbidity is a disturbing factor that alters this scheme in the 'Abra de Bilbao'. Suspension feeders remain the dominant faunal group despite the general algal dominance in the outermost parts of the area (see Fig. 2d). The inner stations, by contrast, are completely dominated by suspension feeders, which even replace the macroalgae on photophilous substrata.

Castric-Fey (1996) found that strong currents were responsible for exuberant subtidal flora on the North Brittany coasts (France), and discussed the differences between the effects of either current- or wave-dominated zones for hard-bottom communities. Turbidity was reported as the ultimate cause of the decline of Fucus on the shallow bottoms of the Kiel bay by Vogt \& Schramm (1991), where Mytilus edulis became dominant after a sequence of biotic and abiotic interactions. As for biotic factors, the relevance of certain invertebrate predators (mainly starfish) in preventing substratum monopolization by mussels is well known in literature (Sebens 1985, Little \& Kitching 1996). By contrast, the absence of such predators was claimed to be the main reason for a bivalve dominance on hard 
bottoms of the Baltic Sea (Littorin \& Gilek 1999). This is also the case of the 'Abra de Bilbao', where the great magnitude of abiotic factors is considered to determine the composition and structure of benthic communities. The almost exclusive role played by environmental factors is in accordance with other studies of sublittoral hard bottom assemblages carried out on semi-enclosed marine areas of Northern Europe (Kluijver \& Leewis 1994, Leewis et al. 1994).

Diversity measures are frequently not considered sensitive enough to detect subtle changes in the composition of communities (Warwick \& Clarke 1991, Dye 1998, Lardicci \& Rossi 1998), nor sufficient by themselves to assess pollution effects (Hughes 1978, Washington 1984). However, while it can never replace a more exhaustive study, a diversity index can be an important tool in benthic monitoring studies, especially when large temporal changes or spatial differences are expected (Gray \& Pearson 1982). Moreover, diversity measures exhibit the advantage of providing a value judgement of the results obtained (Warwick \& Clarke 1991), despite the long theoretical controversy surrounding them. In the present study, the highest values of diversity appear at those sites farthest from the mouth of the Nervión River, i.e. at the most open-sealike stations. In general, the spatial pattern detected by the diversity-related parameters is the same as that produced by biomass-related parameters, thus matching the 2 types of community measurements in their results. A gradation from the optimal conditions for marine life found at the reference station towards the highly stressing characteristics of sites $\mathrm{S}$ or $\mathrm{L}$ is well captured through all these synthetic parameters of community structure.

The intermediate disturbance hypothesis put forward by Connell (1978) represents a genuine contribution in relating diversity to environmental stress. In the study area, the exuberant vegetation found in opensea conditions is accompanied by high taxonomic diversity values of the faunal component, which, in turn, is likely to be promoted by the microhabitats supported by the algal structure itself (Harris 1990, Hily \& Jean 1997). In addition, wave disturbance increases from the inner bay towards more marine-like conditions along the outer stations. According to the synthetic model developed by Menge \& Sutherland (1987), where exclusion competition and high recruitment occur, diversity is at its highest at intermediate rates of disturbance, as could be the case of the 'Abra de Bilbao'. Therefore, we suggest that intermediate conditions of stress occur at geographically intermediate and outermost stations, mainly due to their higher wave exposure. The rest of the investigated area is under larger stressing conditions, given by the addition of wave exposure and higher turbidity levels (see
Fig. 5). In this context, low diversity sites due to low rates of disturbance have not been observed in the 'Abra de Bilbao' and adjacent coast. Accordingly, our hypothesis is that such conditions could be found in a similar bay lacking the turbid discharge of a river.

For the trophic criterion, diversity measures present their minimal values at both extremes of the investigated area, not only in its innermost part. The greater the algal canopy, the greater the dominance of the algal fraction and the lower the trophic diversity. On the other hand, the autotrophic predominance at the outer stations is supporting a high faunal diversity, whereas the dominance of suspension feeders at the inner stations represents, in terms of faunal biomass, comparatively less diverse communities. According to Huston's (1994) model on species diversity and the expectations of this faunal descriptor using different trophic groups, the peak diversity is reached differently after a combination of trophic levels and disturbance rates. For instance a given frequency and intensity of disturbance would eliminate more species at higher trophic levels. Summarizing, the intermediate disturbance situation defines the point at which the total diversity is most evenly distributed among several trophic groups. In the study area, the geographically intermediate stations at Stns P, A, G and N are the most diverse from the functional perspective of the feeding type. Among them, Stn A also presents a high taxonomic diversity. So, given the existence of the aforementioned arrangement of sampling sites along the hard bottoms studied, the station at Arrigunaga (A) could be regarded as a 'key' place, with transitional features between the two major groups of stations. As

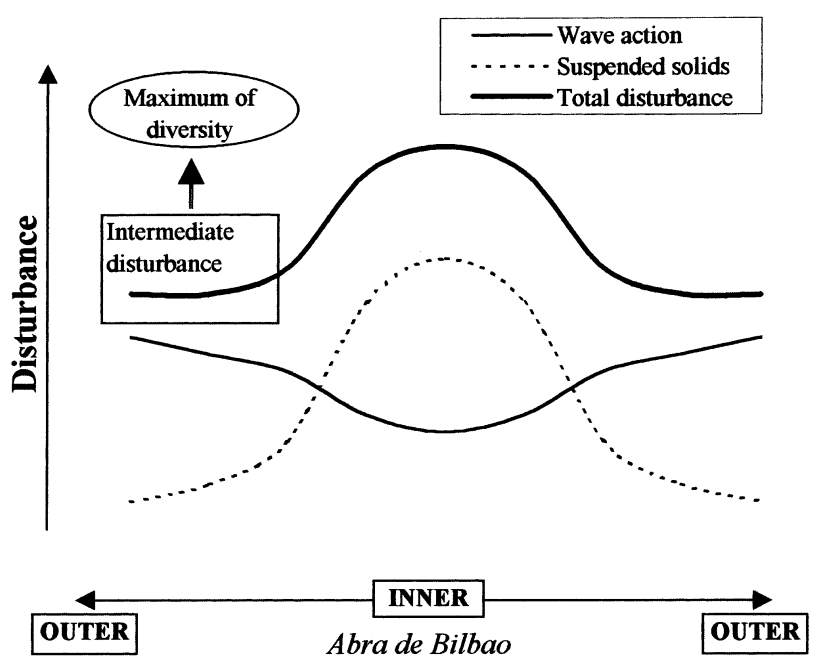

Fig. 5. Schematic representation of the magnitude of the disturbance caused by the most important abiotic factors upon the macrobenthic communities of the 'Abra de Bilbao' hard bottoms and their differential effect on faunal diversity along the axis innermost-outermost (marine-like) zones 
many ideas on biomonitoring can be traced back to the concept of ecological succession (Jan et al. 1994), we could interpret the dualism of this station as an indication of the temporal changes that are taking place within the 'Abra de Bilbao', which are by now quantitative (changes in taxa proportions) rather than qualitative (changes of taxa) in many places. A decrease in suspended solids and water pollution from industrial waste has been noted since 1988 (Gorostiaga \& Díez 1996), as a consequence of the implementation of a sewerage scheme in the city of Bilbao and its conurbation area. A number of changes are expected to occur gradually from a highly stressed condition towards healthier ones. Although the high biotic quality of the reference site is unlikely ever to be found at the most river-influenced parts of the 'Abra de Bilbao', changes relative to benthic biomass such as those expected for Arrigunaga (A) station should be considered in the near future.

Multivariate analyses are powerful statistical tools in establishing groups of similar biotic characteristics along the spatial pattern observed by univariate measures. Therefore, the 2 types of analysis can be regarded as complementary techniques. While the most striking groupings obtained in the results correspond to the relative positions of the 'outer' and 'inner' stations in the MDS plots, the trophic criterion is able to distinguish further intermediate conditions. All this leads us to consider and better propose the validity of the various types of data matrices used for the monitoring of hard bottom communities. From a taxonomic perspective, Olsgard et al. (1997) pointed out the low level of information loss where strong gradients occur, provided that higher categories were employed, even when specimens were identified to the phylum level. That is the case of the 'Abra de Bilbao', as has already been suggested (Urkiaga-Alberdi et al. 1999, PagolaCarte \& Saiz-Salinas 2000). Furthermore, in our study, the information provided by taxonomic-based approaches is practically the same as that obtained by the analyses carried out on the basis of other criteria and levels. In this way, Warwick $(1988 \mathrm{a}, \mathrm{b})$ indicated that the use of higher taxonomic levels might lead to certain theoretical advantages in environmental studies, besides representing practical facilities. Among the advantages, a lesser influence of confounding natural variables was noted after using higher taxonomic levels, a feature that makes it easier to detect pollution effects. In the sublittoral of the 'Abra de Bilbao' we have verified the effect of obtaining additional information by means of the trophic criterion. In fact, a third group of stations was even discernible in the intermediate part of the bay, which showed features, in terms of the biomass of the different trophic components, between the other 2 major groups of sites, as reflected by the results of the SIMPER analysis. It is precisely in that intermediate area (Stns Z, B, A) where the effect of the environmental improvements on the benthic communities could most easily be detected in the coming years. Our expectations are that relevant changes will occur on the sublittoral bottoms of this part of the bay towards typical open-sea photophilous conditions (algal dominance, high taxonomic diversity).

The ability of benthos to integrate environmental conditions over time has been previously noted in many studies (Bilyard 1987, Gray et al. 1990, Diaz 1992, Jan et al. 1994). In the case of the hard bottoms studied here, this fact is again corroborated from different approaches (which we have called criteria) and across a wide spectrum of levels in each case. Two relevant considerations arise from this last point. Firstly, a great weight of evidence is obtained from both univariate measures (see Fig. 2) and multivariate techniques (MDS plots and organisms selected by SIMPER results) illustrating how fauna and flora biomasses are strongly influenced by environmental conditions. The fact that animals tend to monopolize the rocky substrata in the 'Abra de Bilbao', correlates fairly well with lower biomass figures at intermediate areas where the ratio $\mathrm{A} / \mathrm{V}$ is close to 1 . At both sides of this area, one of the 2 biotic compartments dominates, increasing the total biomass of the assemblage as well as the distance from a balanced A/V ratio.

Secondly, the redundancy shown by the biota is substantial in the benthic communities studied. The different aggregation criteria and levels used produced the same result regarding the spatial arrangement of the sampling sites. What is more, the information provided by the 'animal minimal taxa' level, either including or excluding the algae is remarkably similar. The results of the SIMPER analyses point also in the same direction, since a small proportion of the taxa considered in each case is enough to capture the main differences between the groups of stations. The exception is the case of 'proposed taxa' because a greater number of discriminating taxa were selected. It is our belief that a better definition of aggregation levels following objective criteria rather than subjective or even random selection of taxa would provide the best results (but note, in this context, the results of Gray et al. 1988, Clarke \& Warwick 1998). In conclusion, even when the relative importance of fauna and flora has been already emphasized, the several techniques employed in this study reveal the sufficiency of macrofauna for positive use in further monitoring of the area.

On the basis of all these considerations for the 'Abra de Bilbao', a number of conclusions can be drawn regarding the monitoring of hard bottom macrobenthos: (1) The A/V (fauna/flora biomass) ratio on hard bottoms seems to be a sensitive tool for detecting both 
exposure and turbidity effects in marine zones affected by river discharges and reveals itself to be a potential indicator of adverse effects by suspended solids. In addition, a more detailed study using exclusively the macrofaunal component might be enough to fulfill a satisfactory monitoring programme. Nevertheless, further research on similar environments is needed before extending the practical application of our findings to other areas all over the world. (2) There exists a high degree of redundancy on sublittoral assemblages of rocky shores, allowing the development of more costeffective monitoring programmes, by means of the employment of several criteria and levels of data aggregation. (3) The use of several techniques of analysis is not only necessary to assure the consistency of the results (Warwick 1993, Jan et al. 1994), but also recommended in order to obtain further contrasting conclusions from the same data set. In fact, small differences in results obtained with different methods of analysis (univariate, multivariate) or different types of data aggregation (taxonomic, trophic, mixed approaches) may provide other subtle information from the sample site. In our study, Stn A (Arrigunaga) proved to be a 'key' location within the group of stations exhibiting intermediate adverse effects. In this case, our results suggest that the environmental recovery of the area might be taking place faster in those intermediate zones. (4) In view of all the above considerations and recognizing that a community gradation positively reflects the gradient of environmental stress (Pearson 1981), the study of spatial differences using biomass values appears to be a realistic way of beginning longterm monitoring in other pollution-stressed areas.

Acknowledgements. We are grateful to J. Urkiaga, M. Bustamante, J. A. Gonzalez-Oreja and various members of the Department of Plant Biology and Ecology of the University of the Basque Country for help and advice during the study. Thanks are also given to Dr D. M. Dauer and 3 anonymous referees for their comments on the manuscript. At the time of the investigation, S.P.-C. received a post-graduate grant from the Basque Government. We are also grateful to the Consorcio de Aguas Bilbao-Biakaia.

\section{LITERATURE CITED}

Ambrogi AO, Bianchi CN, Morri C, Sconfietti R (1988) Recherches sur la zonation verticale du macrobenthos sessile dans la lagune de Venise. Cah Biol Mar 29:297-311

Bellan G (1984) Indicateurs et indices biologiques dans le domain marin. Bull Ecol 15:13

Bilyard GR (1987) The value of benthic infauna in marine pollution monitoring species. Mar Pollut Bull 18:581-585

Brower JE, Zar JH (1984) Field and laboratory methods for general ecology, 2nd edn. Wm C Brown Publishers, Dubuque, IA

Castric-Fey A (1996) Richesse et biodiversité en mer mégatidale: communautés sublittorales rochauses de la région
Trebeurden-Ploumanac'h (Nord Bretagne, France). Cah Biol Mar 37:7-31

Chapman MG (1998) Relationships between spatial patterns of benthic assemblages in a mangrove forest using different levels of taxonomic resolution. Mar Ecol Prog Ser 162: 71-78

Clarke KR (1993) Non-parametric multivariate analyses of changes in community structure. Aust J Ecol 18:117-143

Clarke KR, Green RH (1988) Statistical design and analysis for a 'biological effects' study. Mar Ecol Prog Ser 46: 213-226

Clarke KR, Warwick RM (1994) Change in marine communities: an approach to statistical analysis and interpretation. Natural Environment Research Council, UK

Clarke KR, Warwick RM (1998) Quantifying structural redundancy in ecological communities. Oecologia 113:278-289

Connell JH (1978) Diversity in tropical rain forests and coral reefs. Science 199:1302-1310

Consorcio de Aguas Comarca del Gran Bilbao (1996) Seguimiento ambiental de los estuarios del Nervión y Barbadún durante 1995. Unpublished report, Bilbao

Consorcio de Aguas Bilbao-Bizkaia (1999) Seguimiento ambiental de los estuarios del Nervión, Barbadún y Butrón durante 1998. Unpublished report, Bilbao

Dauer DM, Luckenbach MW, Rodi AJ Jr (1993) Abundance biomass comparison ( $\mathrm{ABC}$ method): effects of an estuarine gradient, anoxic/hypoxic events and contaminated sediments. Mar Biol 116:507-518

Diaz RJ (1992) Ecosystem assessment using estuarine and marine benthic community structure. In: Burton GA (ed) Sediment toxicity assessment. Lewis, Boca Raton, FL, p $67-85$

Dye AH (1998) Community-level analyses of long-term changes in rocky littoral fauna from South Africa. Mar Ecol Prog Ser 164:47-57

Ellis D (1985) Taxonomic sufficiency in pollution assessment. Mar Pollut Bull 16:459

Ferraro SP, Cole FA (1990) Taxonomic level and sample size sufficient for assessing pollution impacts on the Southern California Bight macrobenthos. Mar Ecol Prog Ser 67: 251-262

Field JG, Clarke KR, Warwick RM (1982) A practical strategy for analysing multispecies distribution patterns. Mar Ecol Prog Ser 8:37-52

Gabriele M, Bellot A, Gallotti D, Brunetti R (1999) Sublittoral hard substrate communities of the northern Adriatic Sea. Cah Biol Mar 40:65-76

Gili JM, Coma R (1998) Benthic suspension feeders: their paramount role in littoral marine food webs. TREE 13:316-321

Glasby TM (1998) Estimating spatial variability in developing assemblages of epibiota on subtidal hard substrata. Mar Freshw Res 49:429-437

Gorostiaga JM, Díez I (1996) Changes in the sublittoral benthic marine macroalgae in the polluted area of 'Abra de Bilbao' and proximal coast (Northern Spain). Mar Ecol Prog Ser 130:157-167

Gray JS (1979) Pollution-induced changes in populations. Phil Trans R Soc Lond B 286:545-561

Gray JS, Pearson TH (1982) Objective selection of sensitive species indicative of pollution-induced change in benthic communities. I. Comparative methodology. Mar Ecol Prog Ser 9:111-119

Gray JS, Aschan M, Carr MR, Clarke KR, Green RH, Pearson TH, Rosenberg R, Warwick RM (1988) Analysis of community attributes of the benthic macrofauna of Frierfjord/Langesundfjord and in a mesocosm experiment. Mar Ecol Prog Ser 46:151-165 
Gray JS, Clarke KR, Warwick RM, Hobbs G (1990) Detection of initial effects of pollution on marine benthos: an example from the Ekofisk and Eldfisk oilfields, North Sea. Mar Ecol Prog Ser 66:285-299

Hartnoll RG (1983) Substratum. In: Earll R, Erwin DG (eds) Sublittoral ecology. The ecology of the shallow sublittoral benthos. Clarendon Press, Oxford, p 97-124

Harris VA (1990) Sessile animals of the sea shore. Chapman and Hall, London

Hatcher AM (1995) Sessile epibiotic biomass on stabilised coal-waste and concrete artificial reefs. Proc 30th Eur Mar Biol Symp, Southampton, UK. Univ Southampton Press, p 319-326

Hatcher AM (1997) Comparison of biomass and percentage cover of sessile epibiota on the Poole Bay artificial reef. Ophelia 47:55-62

Heip C, Warwick RM, Carr MR, Herman PMJ, Huys R, Smol N, Van Holsbeke K (1988) Analysis of community attributes of the benthic meiofauna of Frierfjord/Langesundfjord. Mar Ecol Prog Ser 46:171-180

Hill MO (1973) Diversity and evenness: a unifying notation and its consequences. Ecology 54:427-432

Hily C, Jean F (1997) Macrobenthic biodiversity in intertidal habitats of the Iroise biosphere reserve (Brittany, France). J Mar Biol Assoc UK 77:311-323

Hiscock K (1983) Water movement. In: Earll R, Erwin DG (eds) Sublittoral ecology. The ecology of the shallow sublittoral benthos. Clarendon Press, Oxford, p 58-96

Hiscock K (1985) Aspects of the ecology of rocky sublittoral areas. In: Moore PG, Seed R (eds) The ecology of rocky coasts. Hodder and Stoughton, London, p 290-328

Hughes BD (1978) The influence of factors other than pollution on the value of Shannon's diversity index for benthic macro-invertebrates in streams. Water Res 12:359-364

Huston MA (1994) Non-equilibrium processes and the maintenance of local species diversity. In: Huston MA (ed) Biological diversity. The coexistence of species on changing landscapes. Cambridge University Press, Cambridge, p 110-155

Jan RQ, Dai CF, Chang KH (1994) Monitoring of hard substrate communities. In: Kramer KJM (ed) Biomonitoring of coastal waters and estuaries. CRC Press, Boca Raton, FL, p 285-310

Jenkins SR, Norton TA, Hawkins SJ (1999) Interactions between canopy forming algae in the eulittoral zone of sheltered rocky shores on the Isle of Man. J Mar Biol Assoc UK 79:341-349

Juanes JA, Canteras JC (1995) Monitoring of sewage outfalls in Northern Spain: preliminary studies of benthic communities. Wat Sci Tech 32(2):289-295

Kluijver MJ de (1993) Sublittoral hard-substratum communities off Orkney and St Abbs (Scotland). J Mar Biol Assoc UK 73:733-754

Kluijver MJ de, Leewis RJ (1994) Changes in the sublittoral hard substrate communities in the Oosterschelde estuary (SW Netherlands), caused by changes in the environmental parameters. Hydrobiologia 282/283:265-280

Lardicci C, Rossi F (1998) Detection of stress on macrozoobenthos: evaluation of some methods in a coastal Mediterranean lagoon. Mar Environ Res 45:367-386

Leewis RJ, Waardenburg HW, Tol MWM van der (1994) Biomass and standing stock on sublittoral hard substrates in the Oosterschelde estuary (SW Netherlands). Hydrobiologia 282/283:397-412

Little C, Kitching JA (1996) The biology of rocky shores. Oxford University Press, Oxford

Littorin B, Gilek M (1999) A photographic study of the reco- lonization of cleared patches in a dense population of Mytilus edulis in the northern Baltic proper. Hydrobiologia 393:211-219

Mann KH (1973) Seaweeds: their productivity and strategy for growth. Science 182:975-981

McManus JW, Pauly D (1990) Measuring ecological stress: variations on a theme by RM Warwick. Mar Biol 106: 305-308

McQuaid CD, Branch GM (1984) Influence of sea temperature, substratum and wave action on rocky intertidal communities: an analysis of faunal and floral biomass. Mar Ecol Prog Ser 19:145-151

Menge BA, Sutherland JP (1987) Community regulation, variation in disturbance, competition and predation in relation to environmental stress and recruitment. Am Nat 130: $730-757$

Mettam C (1994) Intertidal zonation of animals and plants on rocky shores in the Bristol Channel and Severn Estuarythe northern shores. Biol J Linn Soc 51:123-147

Navarro E, Iglesias JIP, Pérez Camacho A, Labarta U (1996) The effects of diets of phytoplankton and suspended bottom material on feeding and absorption of raft mussels (Mytilus galloprovincialis Lmk). J Exp Mar Biol Ecol 198: 175-189

Norton TA (1985) The zonation of seaweeds on rocky shores. In: Moore PG, Seed R (eds) The ecology of rocky coasts. Hodder and Stoughton, London, p 7-21

Olsgard F, Somerfield PJ, Carr MR (1997) Relationships between taxonomic resolution and data transformations in analyses of a macrobenthic community along an established pollution gradient. Mar Ecol Prog Ser 149: 173-181

Orive E (1989) Differences in phytoplankton abundance and distribution between the Abra of Bilbao and the adjacent shelf waters. Hydrobiologia 182:121-135

Pagola-Carte S, Saiz-Salinas JI (2000) A pilot study for the monitoring the zoobenthic communities on the rocky shores of Abra de Bilbao (north Spain). J Mar Biol Assoc UK 80:395-406

Palmerini P, Bianchi CN (1994) Biomass measurements and weight-to-weight conversion factors: a comparison of methods applied to the mussel Mytilus galloprovincialis. Mar Biol 120:273-277

Pearson TH (1981) Stress and catastrophe in marine benthic ecosystems. In: Barrett GW, Rosenberg R (eds) Stress effects on natural ecosystems. Wiley-Interscience Publications, Chichester, p 201-214

Rallo A, Gorostiaga JM, Saiz JI, Isasi I, Limia JM (1988) Comunidades bentónicas del Abra de Bilbao y su entorno (N. España). Cah Biol Mar 29:3-19

Reish DJ (1986) Benthic invertebrates as indicators of marine pollution: 35 years of study. Oceans 3:885

Ricciardi A, Bourget E (1998) Weight-to-weight conversion factors for marine benthic macroinvertebrates. Mar Ecol Prog Ser 163:245-251

Ricciardi A, Bourget E (1999) Global patterns of macroinvertebrate biomass in marine intertidal communities. Mar Ecol Prog Ser 185:21-35

Rogers CS (1990) Responses of coral reefs and reef organisms to sedimentation. Mar Ecol Prog Ser 62:185-202

Roth S, Wilson JG (1998) Functional analysis by trophic guilds of macrobenthic community structure in Dublin Bay, Ireland. J Exp Mar Biol Ecol 222:195-217

Saiz-Salinas JI, Isasi-Urdangarin I (1994) Response of sublittoral hard substrate invertebrates to estuarine sedimentation in the outer harbour of Bilbao. PSZN I: Mar Ecol 15: 105-131 
Saiz-Salinas JI, Urkiaga-Alberdi J (1997) Comunidades faunísticas en el intermareal del Abra de Bilbao. Publ Espec Inst Esp Oceanogr 23:121-131

Saiz-Salinas JI, Urkiaga-Alberdi J (1999a) Use of faunal indicators for assessing the impact of a port enlargement near Bilbao (Spain). Environ Monitor Assess 56:305-330

Saiz-Salinas JI, Urkiaga-Alberdi J (1999b) Faunal responses to turbidity in a man-modified bay (Bilbao, Spain). Mar Environ Res 47:331-347

Sale PF, Guy JA (1992) Persistence of community structure: what happens when you change taxonomic scale? Coral Reefs 11:147-154

Schwinghamer P (1981) Characteristic size distributions of integral benthic communities. Can J Fish Aquat Sci 38: 1255-1263

Sebens KP (1985) The ecology of the rocky subtidal zone. Am Sci 73:548-557

Smith RW, Bernstein BB, Cimberg RL (1988) Communityenvironmental relationships in the benthos: applications of multivariate analytical techniques. In: Soule DF, Kleppel GS (eds) Marine organisms as indicators. SpringerVerlag, New York, p 247-326

Somerfield PJ, Clarke KR (1995) Taxonomic levels, in marine studies, revisited. Mar Ecol Prog Ser 127:113-119

Soule DF, Kleppel GS (1988) Marine organisms as indicators. Springer-Verlag, New York

Underwood AJ (1993) The mechanics of spatially replicated sampling programmes to detect environmental impacts in a variable world. Aust J Ecol 18:99-116

Urkiaga-Alberdi J, Pagola-Carte S, Saiz-Salinas JI (1999) Reducing effort in the use of benthic bioindicators. Acta Oecol 20:489-497

Editorial responsibility: Otto Kinne (Editor),

Oldendorf/Luhe, Germany
Villalba A, Viéitez JM (1985) Estudio de la fauna de anélidos poliquetos del sustrato rocoso intermareal de una zona contaminada de la Ría de Pontevedra (Galicia). 1. Resultados biocenóticos. Cah Biol Mar 26:359-377

Vogt H, Schramm W (1991) Conspicuous decline of Fucus in Kiel Bay (Western Baltic): what are the causes? Mar Ecol Prog Ser 69:189-194

Warwick RM (1984) Species size distributions in marine benthic communities. Oecologia 61:32-41

Warwick RM (1986) A new method for detecting pollution effects on marine macrobenthic communities. Mar Biol 92: $557-562$

Warwick RM (1988a) Analysis of community attributes of the macrobenthos of Friefjord/Langesundfjord at taxonomic levels higher than species. Mar Ecol Prog Ser 46: $167-170$

Warwick RM (1988b) The level of taxonomic discrimination required to detect pollution effects on marine benthic communities. Mar Pollut Bull 19:259-268

Warwick RM (1993) Environmental impact studies on marine communities: pragmatical considerations. Aust J Ecol 18: $63-80$

Warwick RM, Clarke KR (1991) A comparison of some methods for analysing changes in benthic community structure. J Mar Biol Assoc UK 71:225-244

Warwick RM, Pearson TH, Ruswahyuni (1987) Detection of pollution effects on marine macrobenthos: further evaluation of the species abundance/biomass method. Mar Biol 95:193-200

Washington HG (1984) Diversity, biotic and similarity indices. A review with special relevance to aquatic ecosystems. Wat Res 18:653-694

Submitted: September 27, 1999; Accepted: August 31, 2000 Proofs received from author(s): February 22, 2001 